\title{
HUBUNGAN SENAM ZUMBA DENGAN KEMAJUAN PERSALINAN PADA IBU BERSALIN KALA 1 FASE AKTIF DI KLINIK BERSALIN TUKAD LUAH DESA TIANYAR KECAMATAN TIANYAR KABUPATEN KARANGASEM. Desak Ketut Sugiartini ${ }^{1)}$ Luh Ayu Purnami ${ }^{2)}$ \\ ${ }^{1)}$ STIKES Buleleng \\ desaksugiartini@yahoo.com \\ ${ }^{2)}$ STIKES Buleleng \\ Ayupurnami40@gmail.com
}

\begin{abstract}
ABSTRAK
Pendahuluan Proses persalinan pada ibu bersalin normal suatu proses yang dapat berlangsung secara alamiah dalam waktu kurang dari 24 jam. Proses persalinan menjadi lebih lancar jika dimasa kehamilannya ibu dianjurkan melakukan senam salah satunya senam zumba yang dapat membantu ibu dalam proses persalinannya. Tujuan penelitian ini adalah untuk mengetahui hubungan Senam Zumba dengan Kemajuan Persalinan Pada ibu bersalin Kala 1 Fase Aktif di Klinik Bersalin Tukad Luah Desa Tianyar Kecamatan Tianyar Kabupaten Karangasem tahun 2018. Metode penelitian dalam peneitian ini adalah penelitian kuantitatif studi analitik dengan metode pendekatan retrospektif. Sampel penelitian sebanyak 32 orang. Tehnik Sampling yang digunakan adalah teknik sampel Nonprobability Sampling yaitu purposive sampling Hasil Hasil penelitian dapat terlihat 32 responden dapat terlihat bahwa sebagian besar umur Ibu adalah usia dengan kriteria 20 - 35 tahun, yaitu 23 ibu (71,9\%), sebagian besar pendidikan ibu SMA, yaitu sebanyak 10 ibu (31,2\%), bahwa sebagian besar pekerjaan ibu dengan kriteria Ibu Rumah Tangga (IRT), yaitu sebanyak 12 responden (37,5\%), dan paritas ibu sebagian besar 2 kali melahirkan sebanyak 12 ibu (37,5\%). Ibu hamil yang melakukan kunjungan ke Klinik Tukad Luah dapat terlihat bahwa sebagian besar teratur melakukan senam zumba, yaitu sebanyak 15 responden (46,9 \%), dapat terlihat bahwa sebagian ibu mengalami kemajuan persalinan normal yaitu sebanyak 19 responden $(59,4 \%)$. Berdasarkan hasil uji chi-square yang didapatkan bahwa $\rho=0,012$ yang berarti $0,012<\alpha 0,05$ artinya H0 ditolak, Ha diterima. Kesimpulan ada Hubungan Senam Zumba dengan Kemajuan Persalinan Pada ibu bersalin Kala 1 Fase Aktif di Klinik Bersalin Tukad Luah Desa Tianyar Kecamatan Tianyar Kabupaten Karangasem tahun 2018. Selain itu dijelaskan dalam dalam uji statistik yang digunakan bahwa 50,0\% senam Zumba mempengaruhi kemajuan persalinan ibu.
\end{abstract}

\section{ABSTRAC}

Introduction The process of labor in normal maternity is a process that can take place naturally in less than 24 hours. The process of childbirth becomes more smoothly if during pregnancy the mother is recommended to do gymnastics one of zumba gymnastics that can help the mother in the process of delivery. The purpose of this study is to determine the relationship of Zumba Gymnastics with Progress of Labor In maternal mothers Kala 1 Active Phase at Maternity Clinic Tukad Luah Tianyar Village Tianyar District Karangasem regency in 2018. Research method in this research is quantitative research analytic study with retrospective approach method. The sample of the study were 32 people. Sampling technique used is sample technique Nonprobability Sampling is purposive sampling. Result Result of research can seen 32 respondents can seen that most of mother age is age with criteria 20 - 35 years old, that is 23 mothers $(71,9 \%)$, mostly education mother high school, as many as 10 mothers $(31,2 \%)$, that most of mother work with criterion of housewife (IRT), that is 12 respondent (37,5\%), and mother parity mostly 2 times giving birth as many as 12 mothers $(37,5 \%)$. Pregnant women who visit Tukad Luah Clinic can be seen that most regularly doing zumba exercise, that is as much as 15 respondents $(46,9 \%)$, can be seen that some mother progressed normal birth that is as much 19 respondents $(59,4 \%)$. Based on result of chi-square test that got $\rho=0,012$ meaning 0,012 $<\alpha$ 0,05 meaning H0 rejected, Ha accepted. Conclusion There is Zumba Gymnastics Relation with Progress of Labor In maternal mother Kala 1 Active Phase at Maternity Clinic Tukad Luah Tianyar Village Tianyar 
District Karangasem Regency in 2018. Also explained in the statistical test used that 50.0\% Zumba exercises affect the progress of maternal delivery.

Keywords: labor, gymnastics, zumba PENDAHULUAN

Masa kehamilan setiap wanita memiliki respon yang berbeda, berupa perubahan fisik terutama bentuk tubuh, dan perubahan hormonal yang terjadi selama kehamilan yang dapat mempengaruhi emosionalnya, kondisi ini menyebabkan wanita hamil menjadi lebih sensitif. Menjelang minggu terakhir menuju kelahiran, kegelisahan dan ketidaknyamanan jasmaniah ibu hamil telah mencapai titik puncaknya. Persalinan merupakan suatu peristiwa kelahiran bayi, primipara mengalami proses persalinan lebih lama dari pada multipara. Persalinan dimulai sejak uterus berkontraksi dan menyebabkan perubahan serviks (membuka dan menipis) berakhir dengan lahirnya plasenta secara lengkap, ibu belum inpartu jika kontraksi uterus tidak mengakibatkan perubahan serviks. Kontraksi uterus mutlak diperlukan untuk mencegah terjadinya perdarahan, kontraksi uterus yang tidak kuat dan terus menerus dapat menyebabkan terjadinya atonia uteri yang dapat mengganggu keselamatan ibu. Melatih otot-otot uterus untuk dapat berkontraksi adekuat salah satu aspek yang akan meningkatkan kemampuan ibu bersalin dalam menghadapi proses persalinan.

Hasil Survei Demografi dan Kesehatan Indonesia (SDKI, 2012) bahwa hasilnya sangat mengejutkan AKI melonjak sangat signifikan menjadi 359 per 100.000 kelahiran hidup yang berati keadaan kembali pada tahun 1997. Ini berarti kesehatan ibu justru mengalami kemunduran selama 15 tahun, terjadi peningkatan signifikan AKI dari 228 (tahun 2007) menjadi 359 (tahun 2012) per 100.000 kelahiran hidup. Terjadinya lonjakan AKI memperlihatkan masih lemahnya sistem kesehatan ibu dan reproduksi di Indonesia. Sungguh mengenaskan, AKI yang sangat tinggi itu artinya Indonesia kini telah berpredikat terbelakang di Asia dalam melindungi kesehatan Ibu.

Hasil SDKII 2012 menjadi sebuah pelajaran bagi Indonesia bahwa saat ini negara gagal memberikan perlindungan bagi Ibu yang melahirkan. Bila melihat target $M D G$ 's 2015 untuk AKI, target Indonesia adalah menurunkan AKI mencapai 102 per 100.000 kelahiran hidup.
Dengan posisi 305 per 100.000 kelahiran hidup pada tahun 2015, yang berati target Melineum Development Goal's (MDG's) tahun 2015 belum dikatakan berhasil maka akan sangat sulit bagi pemerintah untuk mencapai target Sustanabel Development Goal's (SDG's ) pada tahun 2030 AKI di Indonesia akan diturunkan sebesar 70 per 100.000 kelahiran hidup.

Senam pada masa kehamilan ini telah banyak di modifikasi dengan berbagai jenis gerakan dengan harapan tetap dapat memberikan rasa aman dan nyaman pada ibu hamil dan tetap mengutamakan keselamatan bayi. Setiap gerakan pada senam memiliki tujuan dan dapat dilakukan pada saat yang diperlukan sesuai dengan tujuan dari instruktur. Senam Zumba adalah senam yang memadukan gerakan aerobic dengan gerakan lambat. Senam Zumba adalah rangkaian gerakan kardiovaskular yang menyenangkan dan mudah diikuti, diiringi musik. Gerakan aerobik berbasis tarian ini diiringi kombinasi musik Latin dan internasional dengan irama cepat maupun sedang.

Senam zumba bertujuan dapat melaksanakan tugas persalinan dengan kekuatan dan kepercayaan diri sendiri dibawah bimbingan penolong persalinan normal. Melalui senam zumba diperoleh keadaan prima dengan melatih dan mempertahankan otot dinding perut, otot dasar panggul serta jaringan penyangganya untuk berfungsi saat persalinan berlangsung. Senam juga melonggarkan persendian yang berhubungan dengan persalinan, dapat memperbaiki kedudukan janin, meningkatkan ketegangan dan kepercayaan diri menghadapi persalinan, memperoleh pengetahuan dan kemampuan mengatur pernapasan, relaksasi dan kontraksi otot dinding perut, otot sekat rongga badan dan otot dasar panggul saat persalinan. Senam hamil juga dapat meningkatkan kepercayaan pengetahuan tentang kekuatan persalinan sehingga waktu persalinan dapat dipersingkat dan rasa sakit dikurangi. (Muchtar, 2008).

Senam zumba yang berasal dari perpaduan tarian ini akan membantu ibu dalam proses pengalihan rasa nyeri dan membantu proses persalinan. Gerakan dalam zumba dapat menimbulkan peregangan pada otot - otot 
panggul dan melatih pernapasan ibu hamil saat menghadapi rasa nyeri saat kontraksi datang. Pada beberapa penelitian dijelaskan mengenai pengaruh senam tidak hanya zumba yaitu senam hamil dimana hal ini didukung oleh penelitian Riana (2008), yang membandingkan lamanya persalinan kala II pada ibu yang menjalankan senam hamil dan tidak. Hasil yang diperoleh menunjukkan bahwa senam hamil memiliki pengaruh yang signifikan terhadap lama persalinan kala II, khususnya pada primigravida. Lama persalinan kala II pada ibu hamil yang melakukan senam hamil lebih cepat/singkat dibandingan dengan lama persalinan kala II pada ibu hamil yang tidak pernah melakukan senam hamil.

Berdasarkan studi pendahuluan yang dilakukan pada tanggal 7 Januari 2018 di Klinik Bersalin Tukad Luah di Kecamatan Tianyar, bahwa pada 5 ibu bersalin primigravida dengan pembukaan $4 \mathrm{~cm}$ diajak untuk melakukan senam zumba dan di observasi ibu menyatakan rasa nyeri pada kontrasi tidak tidak terlalu dirasakan dan empat jam kemudian di lakukan VT pembukaan ibu maju menjadi bukan 7-8 cm.

Berdasarkan latar belakang tersebut makan peneliti ini melakukan penelitian mengenai "Hubungan Senam Zumba dengan Kemajuan Persalinan Pada ibu bersalin Kala 1 Fase Aktif di Klinik Bersalin Tukad Luah Desa Tianyar Kecamatan Tianyar Kabupaten Karangasem tahun 2018". Penelitian ini bertujuan untuk mengetahui Hubungan Senam Zumba dengan Kemajuan Persalinan Pada ibu bersalin Kala 1 Fase Aktif di Klinik Bersalin Tukad Luah Desa Tianyar Kecamatan Tianyar Kabupaten Karangasem tahun 2018

\section{METODE PENELITIAN}

Rancangan penelitian yang digunakan adalah analitik korelasi yaitu mendeskripsikan variabel bebas dan terikat, kemudian melakukan analisis korelasi antara kedua variabel tersebut. Sehingga dapat diketahui seberapa jauh konstribusi variabel terikat terhadap adanya variabel bebas. Rancangan bangun penelitian ini menggunakan pendekatan Cross sectional yaitu pengukuran variabel bebas dan terikat hanya satu kali pada satu saat (Notoatmodjo, 2007). Sampel dalam penelitian ini adal 32 responden, tempat pelaksanaan di Klinik Tukad Luah Tianyar Karangasem Bali, dilaksanakan pada bulan
Januari sampai Maret 2018. Pengambilan data menggunakan kuesioner dan observasi langsung

\section{HASIL DAN PEMBAHASAN}

Hasil penelitian dapat terlihat 32 responden dapat terlihat bahwa sebagian besar umur Ibu adalah usia dengan kriteria 20 - 35 tahun, yaitu $23 \mathrm{ibu}$ (71,9\%), sedangkan yang paling sedikit adalah ibu dengan kriteria > 35 tahun, yaitu sebanyak 3 ibu $(10,1 \%)$. Pada tabel 5.2 dari 32 ibu dapat terlihat bahwa sebagian besar pendidikan ibu SMA, yaitu sebanyak $10 \mathrm{ibu}$ $(31,2 \%)$, sedangkan yang paling sedikit adalah ibu dengan kriteria pendidikan SMP yaitu sebanyak 9 ibu $(28,1 \%)$. Pada 32 ibu dapat terlihat bahwa sebagian besar pekerjaan ibu dengan kriteria Ibu Rumah Tangga (IRT), yaitu sebanyak 12 responden $(37,5 \%)$, sedangkan yang paling sedikit adalah responden dengan pedagang, yaitu sebanyak 3 responden $(9,4 \%)$ dan paritas ibu sebagian besar 2 kali melahirkan sebanyak 12 ibu $(37,5 \%)$, sedangkan yang paling sedikit adalah ibu yang melahirkan > 4 kali, yaitu sebanyak 2 responden (6,2 \%). Pada 32 ibu hamil yang melakukan kunjungan ke Klinik Tukad Luah dapat terlihat bahwa sebagian besar teratur melakukan senam zumba, yaitu sebanyak 15 responden (46,9 \%), sedangkan tidak pernah, yaitu sebanyak $5 \mathrm{ibu}(15,6 \%)$ dan dapat terlihat bahwa sebagian ibu mengalami kemajuan persalinan normal yaitu sebanyak 19 responden $(59,4 \%)$. Sedangkan sebanyak 13 responden $(40,6 \%)$ kemajuan persalinan tidak normal. Berdasarkan hasil uji chi-square yang didapatkan bahwa $\rho=0,012$ yang berarti $0,012<\alpha 0,05$ artinya $\mathrm{HO}$ ditolak, Ha diterima yang artinya ada Hubungan Senam Zumba dengan Kemajuan Persalinan Pada ibu bersalin Kala 1 Fase Aktif di Klinik Bersalin Tukad Luah Desa Tianyar Kecamatan Tianyar Kabupaten Karangasem tahun 2018. Selain itu dijelaskan dalam dalam uji statistik yang digunakan bahwa $50,0 \%$ senam Zumba mempengaruhi kemajuan persalinan ibu.

Kehamilan adalah proses yang alamiah dan fisiologis yang dialami wanita. Umunya, setelah umur kehamilan 40 minggu jika tidak ada penyulit dan penyakit penyerta maka wanita hamil akan mengalami proses persalinan yaitu serangkaian proses yang berahir dengan pengeluaran hasil konsepsi. Untuk meningkatkan derajat kesehatan ibu, pemerintah mencanangkan 
program asuhan antenatal. Senam Zumba dimulai setelah kehamilan 28 minggu dan minimal dilakukan selama 30-60 menit. Senam zumba bukan merupakan keharusan, namun dengan melakukan senam zumba akan memberikan banyak manfaat dalam proses persalinan (Datta, 2008) Pergerakan dan latihan dari senam zumba tidak saja menguntungkan sang ibu, hal ini dikarenakan gerakan Zumba memiliki bermacammacam gerakan yang dimulai dari gerakan salsa. Gerakan salsa adalah gerakan menari lembut dengan iringan music klasik sehingga dapat membantu pula dan juga sangat berpengaruh terhadap kesehatan bayi yang dikandungnya. Pada saat bayi mulai dapat bernafas sendiri, maka oksigen akan mengalir kepadanya melalui plasenta, yaitu dari aliran darah ibunya ke dalam aliran darah bayi yang dikandung. Music klasik yang didengar ibu akan membantu ibu dalam mengurangi kecemasan saat persalinan nanti. Senam Zumba akan menambah jumlah oksigen dalam darah di seluruh tubuh sang ibu dan karena itu aliran oksigen kepada bayi melalui plasenta juga akan menjadi lancar (Sani; 2002). Latihan senam zumba tidak dapat dikatakan sempurna bila penyajiannya tidak disusun secara teratur yaitu minimal satu kali dalam seminggu yang dimulai saat umur kehamilan 28 minggu. Dengan mengikuti senam zumba secara teratur dan intensif, wanita tersebut akan menjaga kesehatan tubuhnya dan janin yang dikandungnya secara optimal (Evariny; 2012).

Masih banyak ibu hamil yang meragukan apakah melakukan gerakan senam zumba aman untuk kehamilannya atau tidak. Kegiatan senam ringan, berjalan santai, juga berenang dapat membantu anda untuk menstimulasi kerja jantung dan otot-otot saat persalinan. Senam dan berenang membantu memanfaatkan oksigen dan meningkatkan sirkulasi darah, serta memperkuat otot perut dan bahu (Widianti, 2010).

Berdasarkan hasil penelitian Sri Wahyuni (2009), hasil penelitian diperoleh bahwa dari 15 ibu hamil yang mengikuti senam zumba ternyata $80 \%$ proses persalinanya normal, dan $20 \%$ proses persalinannya tidak normal, sedangkan 15 ibu hamil yang tidak mengikuti senam zumbal $66,66 \%$ persalinannya tidak normal, dan 33,33\% proses persalinannya normal. Dan dapat disimpulkan bahwa terdapat Hubungan yang signifikan antara senam zumba dengan proses persalinan di RSIA Aisyiyah Klaten dengan nilai $\mathrm{p}=0,003<0,05$. Hasil penelitian ini didukung oleh penelitian yang dilakukan oleh Bernadita (2017), bahwa terdapat hubungan senam zumba dengan proses persalinan di klinik $\mathrm{Hj}$ Endang Tungkak Yogyakarta. Hasil penelitian ini sejalan dengan pendapat Muchtar (2008), bahwa senam yang teratur dapat membantu proses persalinan berlangsung alami dan lancar.

Menurut hasil penelitian Elizawarda (2013) tetang Studi kasus kelola faktor resiko untuk pencegahan lama persalinan di Rumah Sakit Umum Dr Pirngadi Kota Medan menunjukkan adanya hubungan yang signifikasi antara senam dengan kejadian lama persalinan. Berdasarkan hasil penelitian dan teori diatas, peneliti berasumsi bahwa kemajuan persalinan dipengaruhi oleh faktor senam zumba. Akan tetapi ada beberapa ibu yang tidak melakukan senam zumba namun mengalami kemajuan persalinan hal ini disebabkan oleh karena faktor lain yaitu ibu melakukan senam hamil di puskesmas dan ibu mampu melakukan teknik pernapasan yang baik, sedangkan ibu yang melakukan senam zumba namun tidak mengalami kemajuan persalinan kemungkinan disebabkan oleh faktor ibu merupakan primigravida sehingga pengetahuannya kurang baik tentang teknik pernapasan yang baik

Sejalan dengan penelitian Lingga Maharani, 2014 Kehamilan dan persalinan yang mempunyai risiko adalah anak pertama dan anak keempat atau lebih karena pada anak pertama dan persalinan anak keempat atau lebih karena pada anak pertama adanya kekakuan dari otot atau serviks yang kaki memberikan tahan yang jauh lebih besar dan dapat memperpanjang persalinan sedangkan pada anak keempat atau lebih adanya kemunduran daya lentur (elastisitas) jaringan yang sudah berulang kali diregangkan kehamilan, sehingga nutrisi yang dibutuhkan janin berkurang, dinding rahim dan dinding perut kendor kekenyalan sudah kurang sehingga dapat memperpanjang proses persalinan.

Pada hasil penelitian bahwa sebagian besar umur Ibu adalah usia dengan kriteria 20 35 tahun. Usia ibu kurang dari 20 tahun atau lebih dari 35 tahun, pertambahan umur akan diikuti oleh perubahan organ dalam rongga pelvis. 
Keadaan ini akan mempengaruhi kehidupan janin dalam rahim. Pada wanita usia muda dimana organ-organ reproduksinya belum sempurna secara keseluruhan, disertai kejiwaan yang belum bersedia menjadi seorang ibu. Usia perempuan untuk hamil dan melahirkan memiliki pengaruh yang berbeda pada kesehatan ibu dan janinnya.

Kehamilan dan persalinan di bawah umur 20 tahun memiliki resiko yang sama tingginya dengan kehamilan umur 35 tahun keatas sehingga dapat menimbulkan resiko. Usia berkaitan dengan masalah kesehatan, resiko akan meningkat sejalan dengan usia. Persalinan pada ibu usia tua dapat menimbulkan kecemasan yang mengakibatkan persalinan yang lebih sulit dan lama. Umur ibu tidak secara langsung berpengaruh terhadap kejadian asfiksia neonatorum, namun demikian telah lama diketahui bahwa umur berpengaruh terhadap proses reproduksi. Umur yang dianggap optimal untuk kehamilan adalah antara 20-35 tahun. Sedangkan dibawah atau diatas usia tersebut akan meningkatkan risiko kehamilan maupun persalinan. Umur ibu pada waktu hamil sangat berpengaruh pada kesiapan ibu untuk menerima tanggung jawab sebagai seorang ibu sehingga kualitas sumber daya manusia makin meningkat dan kesiapan untuk menyehatkan generasi penerus dapat terjamin. Kehamilan di usia mudah/remaja (dibawah usia 20 tahun) akan mengakibatkan rasa takut terhadap kehamilan dan persalinan, hal ini dikarenakan pada usia tersebut ibu mungkin belum siap untuk mempunyai anak dan alat-alat reproduksi ibu belum siap untuk hamil. begitu juga kehamilan di usia tua (di atas 35 tahun) akan menimbulkan kecemasan terhadap kehamilan dan persalinannya serta alat reproduksi ibu terlalu tua untuk hamil.

\section{KESIMPULAN}

Setelah dilakukan penelitian tentang Hubungan Senam Zumba dengan Kemajuan Persalinan Pada ibu bersalin Kala 1 Fase Aktif di Klinik Bersalin Tukad Luah Desa Tianyar Kecamatan Tianyar Kabupaten Karangasem tahun 2018 dari 32 responden, maka dapat diambil kesimpulan sebagai berikut : Hasil penelitian dapat terlihat 32 responden dapat terlihat bahwa sebagian besar umur Ibu adalah usia dengan kriteria 20 - 35 tahun, yaitu 23 ibu (71,9\%), sebagian besar pendidikan ibu SMA, yaitu sebanyak 10 ibu $(31,2 \%)$, bahwa sebagian besar pekerjaan ibu dengan kriteria Ibu Rumah Tangga (IRT), yaitu sebanyak 12 responden $(37,5 \%)$, dan paritas ibu sebagian besar 2 kali melahirkan sebanyak 12 ibu (37,5\%). Ibu hamil yang melakukan kunjungan ke Klinik Tukad Luah dapat terlihat bahwa sebagian besar teratur melakukan senam zumba, yaitu sebanyak 15 responden $(46,9 \%)$, dapat terlihat bahwa sebagian ibu mengalami kemajuan persalinan normal yaitu sebanyak 19 responden $(59,4 \%)$. Berdasarkan hasil uji chi-square yang didapatkan bahwa $\rho=0,012$ yang berarti $0,012<\alpha 0,05$ artinya $\mathrm{H} 0$ ditolak, Ha diterima yang artinya ada Hubungan Senam Zumba dengan Kemajuan Persalinan Pada ibu bersalin Kala 1 Fase Aktif di Klinik Bersalin Tukad Luah Desa Tianyar Kecamatan Tianyar Kabupaten Karangasem tahun 2018. Selain itu dijelaskan dalam dalam uji statistik yang digunakan bahwa 50,0\% senam Zumba mempengaruhi kemajuan persalinan ibu. Disarankan agar dapat dijadikan informasi mengenai metode memperlancar proses persalinan pada ibu hamil sehingga ibu lebih mengenali tanda - tanda persalinan dan mengatasi kecemasan saat bersalin nanti Diharapkan penelitian ini dapat Sebagai bahan masukan untuk tindak lanjut program KIA dalam memberikan pelayanan terbaik bagi ibu hamil dan bersalin untuk mencapai target yang diharapkan Diharapkan dapat dijadikan Sebagai bahan bacaan untuk menambah wawasan ilmu pengetahuan meningkatkan mutu pendidikan tentang kesehatan yang berhubungan dengan kehamilan dan persalinan.

Hasil penelitian ini diharapkan dapat dijadikan sebagai bahan perbandingan untuk penelitian selanjutnya dengan variabel yang berbeda seperti pengetahuan, faktor fisik, faktor psikologis, dan lain-lain.

\section{REFERENSI}

Alimul, H. 2006. Metode Penelitian Keperawatan \& Tehnik Analisis Data. Salemba Medika. Jakarta

Amir, I, 2008, Penyakit dan Perlukaan Pada Bayi Baru Lahir, Dalam: Saifudin, Abdul 
Bari, 2008. Ilmu Kebidanan, Jakarta, YBPSP.

APN, 2011, Asuhan Persalinan Normal Dan Inisiasi Menyusui Dini, Jakarta, JNPKKR.

Armi, 2006, Dasr-Dasar Ilmu Kebidana,. Padang, Andalas University Press.

BKKBN, 2006, Deteksi Dini Komplikasi Persalinan, Jakarta, BKKBN.

Bobak, et al,2005, Keperawatan Maternitas, Jakarta, EGC.

Carey, J, 2005, Ilmu Kesehatan Obstetri Patologi Reproduksi, Edisi 2, Jakarta, EGC.

Chapman, V, 2006, Asuhan Kebidanan Persalinan dan Kelahiran (The Midwie's Labour and Birth Hanbook), Jakarta: EGC.

Cunningham, dkk, 2009, Obstetri Williams, Jakarta, EGC.

Cunningham, dkk, 2012, Obstetri Williams, Jakarta, EGC.

Errol, Norwitz dan John O, Schorge, 2007, Persalinan Premature, Dalam Safitri, Amalia dan Rina Astikawati (editor). At a Glance dan Ginekologi, Jakarta, Erlangga

Fajar, Ibnu, dkk, 2009 Statistika Untuk Praktisi Kesehatan, Graha Ilmu, Jogjakarta.

Handiyah, 2013, Hubungan paritas dengan kejadian ruptur perineum pada ibu bersalin di RSUD dr. Wahidin Sudirohusodo Mojokerto tahun 2013, Laporan Penelitian.

Kementerian, Kesehatan, RI, Rencana Aksi Percepatan Penurunan AKI 2013-2015, Jakarta, Kementerian Kesehatan RI.
Kementerian, Kesehatan, RI, Profil Kesehatan Indonesia 2013, Jakarta, Kementerian Kesehatan RI.

Martaadisoebrata, dk,. 2009, Bunga Rampai Obstetri dan Ginekologi Sosial, Jakarta, YBP-SP.

Maryunani, A, Puspita, E, 2013, Asuhan Kegawatdaruratan Maternal dan Neonatal, TIM, Jakarta.

Manuaba IBG, 2010, Ilmu Kebidanan, Penyakit Kandungan dan Keluarga Berencana Untuk Pendidikan Bidan, Jakarta, ECG.

Mochtar, R, 2011, Sinopsis Obstetri Fisiologi Patologi, Jilid 1 Edisi 3, Jakarta, EGC.

Musbikin, I. 2006, Ibu Hamil dan Melahirkan, Yogyakarta, Mitra Pustaka.

Notoadmodjo, S, 2012, Metodologi Penelitian Kesehatan, Jakarta, Rineka Cipta.

Nugroho, Taufan, 2012, Obstetri dan Ginekologi, Jakarta, Nuha Medika.

Nurasiah, A, dkk, 2012, Asuhan Persalinan Normal Bagi Bidan, Bandung, PT Refika Aditama.

Nursalam, 2008, Konsep Dan Penerapan Metodologi Penelitian Ilmu Keperawatan, Jakarta, Salemba Medika.

Oxorn H, Forte WR, 2010, Ilmu Kebidanan Patologi dan Fisiologi Persalinan, Yogyakarta, Yayasan Essentia Medica.

Pasiowan, Stella, 2015, Faktor-Faktor Yang Berhubungan Dengan Robekan Jalan Lahir Pada Ibu Bersalin, Jurnal Ilmiah Bidan, vol. 3. 2015.

Penny, Simkin, Ruth, Ancheta, 2005. Buku Saku Persalinan, Jakarta, EGC.

Prawitasari, dkk. 2015, Penyebab Terjadinya Ruptur Perineum pada Persalinan Normal

http://ejournal.stikesbuleleng.ac.id/index.php/Midwinerslion | 88 
di RSUD Muntilan Kabupaten Magelang, Jurnal Ners dan Kebidanan Indonesia, vol. 2015.

Prawirohardjo, S, 2014, Ilmu Kebidanan, Edisi 4, Jakarta, PT Bina Pustaka Sarwono Prawirohardjo.

Rahayu, 2014, Faktor Yang Berhubungan Dengan Kejadian Ruptur Perineum Di Puskesmas Mergangsan Kota Yogyakarta Tahun 2014, Jurnal Medika Respati, vol. XI. 2016.

Riyanto, Agus. 2013. Statistik Inferensial Untuk Analisa Data, Yogyakarta: Nuha Medika.

Rukiyah, A, Y, dan Yulianti, Lia, 2012, Asuhan Kebidanan 4 (Patologi), Jakarta, Trans Info Media.

Saifuddin, A, B, dkk, 2010, Ilmu Kebidanan Sarwono Prawirohardjo, Jakarta

Bina Pustaka Sarwono Prawirohardjo.

Saryono, 2011, Metodologi Penelitian Kebidanan, Yogyakarta, Nuha Medika, Pustaka Cendikia Press.

Sugiyono, 2012, Statistika Untuk Penelitian, Bandung, Alfabeta.

Sukrisno, Adi, 2010, Asuhan Kebidanan IV (Patologi Kebidanan), Jakarta, Trans Info Media

sukarni, 2013, Buku Ajar Keperawatan Maternitas, Yogyakarta, Nuha Medika.

Suririnah, 2008, Buku Pintar Kehamilan \& Persalinan, Jakarta, Gramedia Pustaka Utama.

Varney, H, 2008, Buku Ajar Asuhan Kebidanan, Edisi 4, Volume 2, Jakarta, EGC.

Varney, H, 2007, Buku Ajar Asuhan Kebidanan, Edisi 4, Volume 1, Jakarta, EGC.
Wiknjosastro, Hanifa, 2013, Ilmu Kebidanan, Jakarta, Yaysan Bina Pustaka Sarwono. 